Vol. 6, No. 1, January, 2020

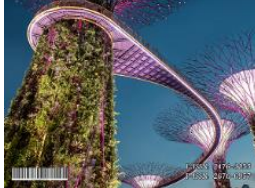

\title{
Cost Comparison of a Building Project by Manual and BIM
}

\author{
Usman Haider ${ }^{\mathrm{a}^{*}}$, Usama Khan ${ }^{\mathrm{b}}$, Asif Nazir ${ }^{\mathrm{b}}$, Muhammad Humayon ${ }^{\mathrm{c}}$ \\ ${ }^{a}$ Department of Mechanics, Faculty of Civil Engineering, Czech Technical University in Prague, Czech Republic. \\ ${ }^{b}$ Department of Technology, Branch of Civil Engineering Technology, The University of Lahore, Pakistan. \\ ${ }^{c}$ Parsons Transportation Group,3577 Parkway lane, Peachtree Corners, GA, USA.
}

Received 16 August 2019; Accepted 20 November 2019

\begin{abstract}
This article focuses on comparison between Manual/Traditional and Building Information Modelling (BIM) software based approaches for cost comparison. Centre line method for manual and Revit software for BIM based approaches are used in this research. The principal objectives of this research are to calculate quantities by Manual Centre line method, then to make the cost estimation fast, accurate, efficient, and errorless by using BIM software Rivet, and finally the comparison study of manual based and BIM / Software based estimation. For manual approach, quantities are calculated by multiplying the measurements of length, breadth, and height. Then to get the total quantities the deduction is subtracted from the quantities and final BOQ is prepared for which estimated cost of building is calculated. For BIM based approach, 3D model from 2D floor plan of building is prepared in Revit software, then to estimate the cost of building structure elements, sheets of quantities are generated in the schedule option of the view tab in the software. The Percentage difference between Manual and BIM / Revit Software estimation in brick work, RCC Slab, Plaster Work, PCC for Flooring, Floor Tile Work, Skirting, Paint Work, False Ceiling, Doors and Aluminum Work is 4.57, 2.61, 7.58, 3.27, 1.87, 6.73, 8.03, 1.87, and 0.00\% respectively. The total cost difference between manual and BIM based estimation approach comes out to be $4.8 \%$. It is thus concluded that the BIM-assisted estimates have better performance over traditional/manual estimating methods.
\end{abstract}

Keywords: Cost; Manual; Building; Revit Software; Estimate; BIM.

\section{Introduction}

Cost estimation is initial stage for any construction project; it helps to evaluate project feasibility, cost controls, and tendering process [1,2]. There are two types of cost estimation rough cost estimation and detailed cost estimation. Rough cost estimate can be an approximate estimate to find an approximate cost of a task based on plinth area rates very quickly and therefore it permits the competent authority worried to consider the financial aspects of the scheme for administrative authorization to the design [3]. Whereas, detailed cost estimation includes the specific particulars of the quantities, rates, and costs of all items for according technical sanction, tendering, and for satisfactory completion of a project [4]. There are two types of cost estimation method according to their generation, Manual and Building Information Modelling (BIM) [5]. In Manual detailed estimation approach, center line method is used for estimation in buildings where cross wall are not provided. In this method first we have to find the total length of the wall and then multiply it with the width and its height to get the volume [6]. In order to prepare a detailed manual estimate, the estimator must have the drawings of the work such as plans and sections for taking measurements, identification of the nature of materials specifications to be used, and their rates at which the different items of work are carried out as per the Market Rate System (MRS) of the Finance Department, Government of the Punjab [7] to obtain the Bill of Quantities (BOQ). In order to prepare a

* Corresponding author: usmanhaider6886@gmail.com

http://dx.doi.org/10.28991/cej-2020-03091451

(C) 2019 by the authors. Licensee C.E.J, Tehran, Iran. This article is an open access article distributed under the terms and conditions of the Creative Commons Attribution (CC-BY) license (http://creativecommons.org/licenses/by/4.0/). 
detailed Building Information Modelling (BIM) / Software based estimate the estimator must have prepared 3D model of the building structure and must obtain its quantities for different class of materials taken from the software [8,9]. After this, rates taken from MRS system of the Finance Department, Government of the Punjab are inserted in the software to obtain the Bill of Quantities (BOQ).

With BIM Software, the software produces suitable specific and correct cost estimation for every single examined project. This technique generates estimation of construction jobs with more accuracy and reliability [10]. Building Information Modelling (BIM) technology improves the incorrectness in cost estimation and helps to reduce the cost of the project [5]. Building Information Modeling (BIM) generates accurate information and allows project collaborators to easily access information of various types, greatly promoting information transparency during the lifecycle of a facility. The quick adoption of BIM services and products is because of the benefits it offers to adopting companies. Moreover, BIM adoption may result in a positive return on the BIM investment for project collaborators through savings from reduced project costs. Literature is full of evidence which supports to demonstrate that BIM adoption supports the reduction of design and construction cost, increase in productivity, and improved risk management processes. BIM models richly describe buildings through classes of objects that contain their 3D geometry and other characteristics. Quantity can be measured automatically from BIM models by extracting geometric data and semantic properties of each building element [11-15].

There are two phases of cost estimation, one at the time of design of the project and second is at the time of construction. Estimation at the time of design helps for the project feasibility, project budget etc. Estimation at the time of construction should be done when additional construction is required with the use of information technology in cost estimation. At the time of design information technology helps us to provide support in making the cost estimate, maintaining of cost database and to save the record easily. Information technology helps construction estimation by maintaining the project data and items of work on project. Building cost estimation is very important for tendering process as it helps contractors and clients in comparing for the volume and price from different bidders [16, 17].

Cost estimation for building projects traditionally starts with tendering process. The process of manual cost estimation is prone to human error and tends to propagate inaccuracies. While the use of BIM software is to increase the accuracies of the cost estimation. Computer based estimating (Revit/BIM software) systems have gained a wide acceptance in the construction industry. It is widely used in construction management in the developed countries. In the developing countries using computers software for cost estimation is still at the early stages. Therefore, there is a dire need in countries such as Pakistan to do cost estimation by BIM software. The principal objectives of this research are to calculate quantities by manual centre line method, to make the cost estimation fast, accurate, efficient, and errorless by using BIM software Rivet, and finally the comparison study of manual based and BIM / Software based estimation.

\section{Methodology}

The adopted methodology to accomplish this study includes comparison of cost estimation by manual approach and by BIM software based approach as shown in Figure 1.

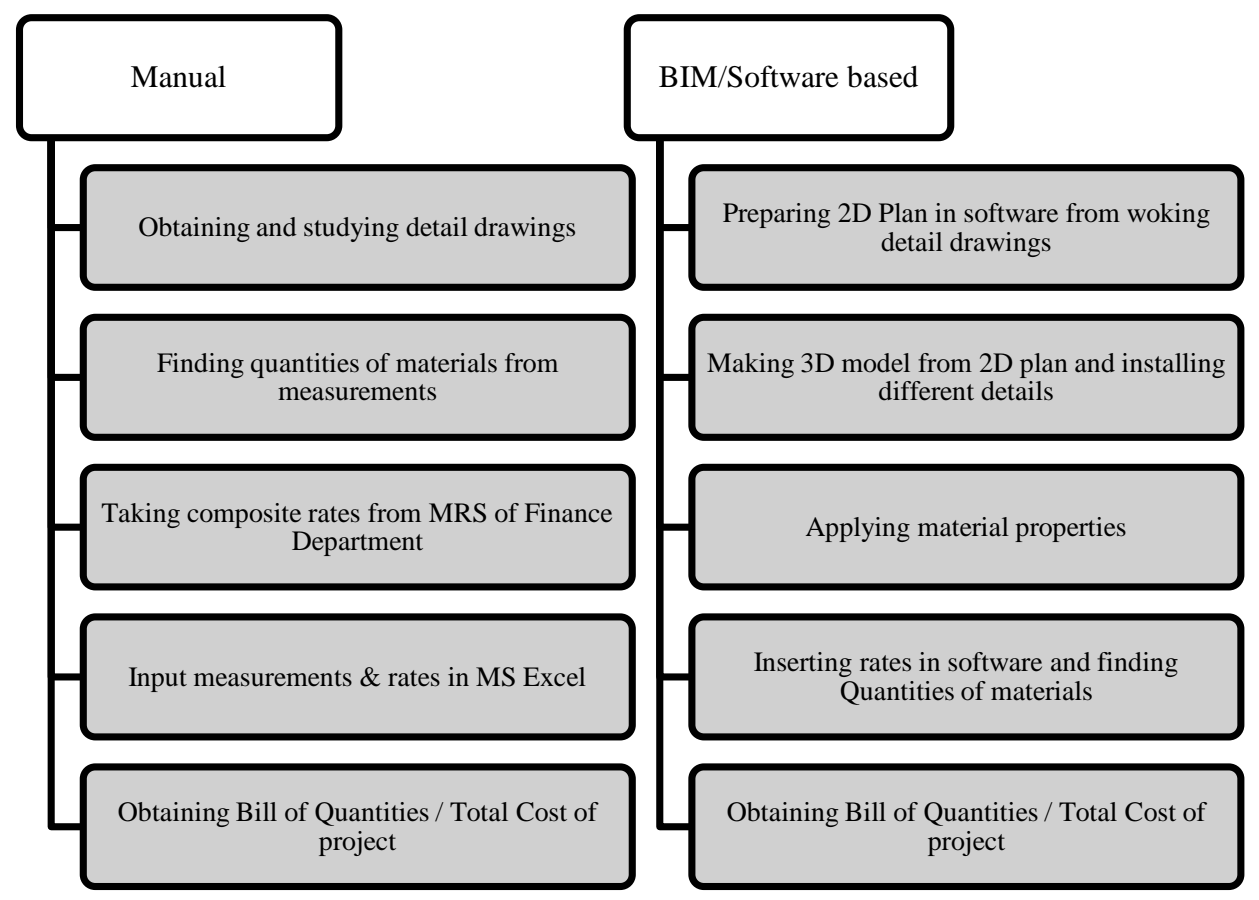

Figure 1. Comparison of Manual and BIM Software based estimation 
Basic requirements for both Manual and BIM methods is the selection of site and collection of data. The site of college located in Bahria town near Multan road Lahore is selected for cost estimation in this research. Moreover, working drawings, layout plans, elevation, structural slab drawings were collected for this research on cost estimation. The step by step procedure to carry out cost estimation by manual and BIM approaches are as follows:

\subsection{For Manual Cost Estimation}

1. To carry out manual estimation the drawing of the project such as plans and sections are taken in hand.

2. Exact nature and class of materials to be used are to found.

3. Different Formulas which are used for cost estimation in manual approach are as shown in Table 1

4. In the manual approach, center line method is used for cost estimation as shown in Figure 2.

5. In this method first the total length of the wall is found and then it is multiplied with the width and its height to get the volume [6].

6. Rates are found at which the different items of work are carried out as per the MRS system from the website of the Finance Department, Government of the Punjab, Pakistan.

7. Detailed estimation sheet of each item is prepared.

8. After this, following things are calculated:

- Quantities of items.

- Composite rates from MRS

- Abstract of total cost.

- Preparation of bill of quantities.

Table 1. Formula sheet for manual cost estimation

\begin{tabular}{clcc}
\hline Sr. No & Item Name & Unit & Formula \\
\hline 1 & Brick Work & $\mathrm{Cft}$ & $\mathrm{L} \times \mathrm{B} \times \mathrm{H}$ \\
2 & RCC Slab & $\mathrm{Cft}$ & $\mathrm{L} \times \mathrm{B}$ \\
3 & Plaster Work & $\mathrm{Sft}$ & $\mathrm{B} \times \mathrm{H}$ \\
4 & PCC for Flooring & $\mathrm{Cft}$ & $\mathrm{L} \times \mathrm{B} \times \mathrm{H}$ \\
5 & Floor Tile Work & $\mathrm{Sft}$ & $\mathrm{L} \times \mathrm{B}$ \\
6 & Skirting & $\mathrm{Rft}$ & Running foot \\
7 & Paint Work & $\mathrm{Sft}$ & $\mathrm{L} \times \mathrm{B}$ \\
8 & False Ceiling & $\mathrm{Sft}$ & $\mathrm{L} \times \mathrm{B}$ \\
9 & Doors & $\mathrm{Sft}$ & $\mathrm{L} \times \mathrm{B}$ \\
10 & Aluminium Work & $\mathrm{Sft}$ & $\mathrm{L} \times \mathrm{B}$ \\
\hline
\end{tabular}

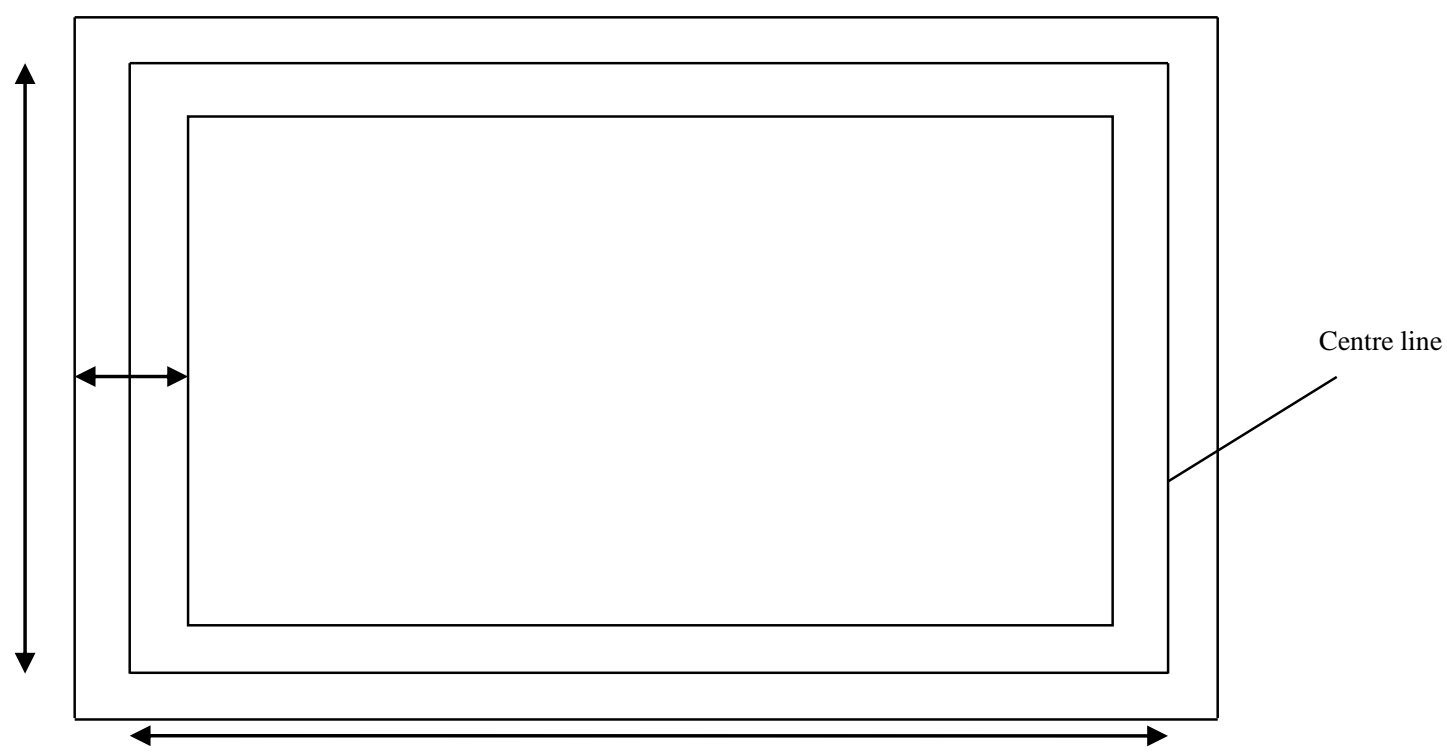

Figure 2. Centre Line method 


\subsection{For BIM / Software Approach}

1. For BIM based approach, Revit software as shown is to be used in this research.

2. 2D floor plan of the project was drawn in Revit software.

3. 2D floor plan is converted into 3D model of the structure.

4. The building elements and material are identified.

5. After this the quantities for each component are obtained [5,9].

6. Rates of each item as shown in Table 2 are taken from the MRS system of the first Bi-Annual 2019 of the Finance Department, Government of the Punjab, Pakistan and are inserted in the software.

7. Detailed estimation of quantities of each item is obtained from software

8. Abstract of total cost and bill of quantities is calculated from software.

9. After this, aabstract of total cost and bill of quantities are taken from software [19].

Table 2. Rates of items taken from MRS first Bi-Annual 2019 [19]

\begin{tabular}{cccc}
\hline Sr. No & Item Name & Unit & Composite rates (Rupees) \\
\hline 1 & Brick Work in Super Structure & $\mathrm{Cft}$ & 222 \\
2 & RCC Slab & $\mathrm{Cft}$ & 360 \\
3 & Plaster Work & $\mathrm{Sft}$ & 180 \\
4 & PCC for Flooring & $\mathrm{Cft}$ & 135 \\
5 & Floor Tile Work & $\mathrm{Sft}$ & 300 \\
6 & Skirting & $\mathrm{Rft}$ & 100 \\
7 & Paint Work & $\mathrm{Sft}$ & 45 \\
8 & False Ceiling & $\mathrm{Sft}$ & 65 \\
9 & Doors & $\mathrm{Sft}$ & 700 \\
10 & Aluminium Work & $\mathrm{Sft}$ & 550 \\
\hline
\end{tabular}

\section{Results and Discussions}

Detailed calculation of quantities in manual cost estimation along with model based calculation for BIM software [20] based method are carried out.

\subsection{Manual Cost Estimation}

In manual cost estimation, quantities of different items are calculated step by step as explained below by using the architectural plan as shown in Figure 3. In this figure, five colours red, blue, magenta, green, and black are used to distinguish different wall sections from each other.

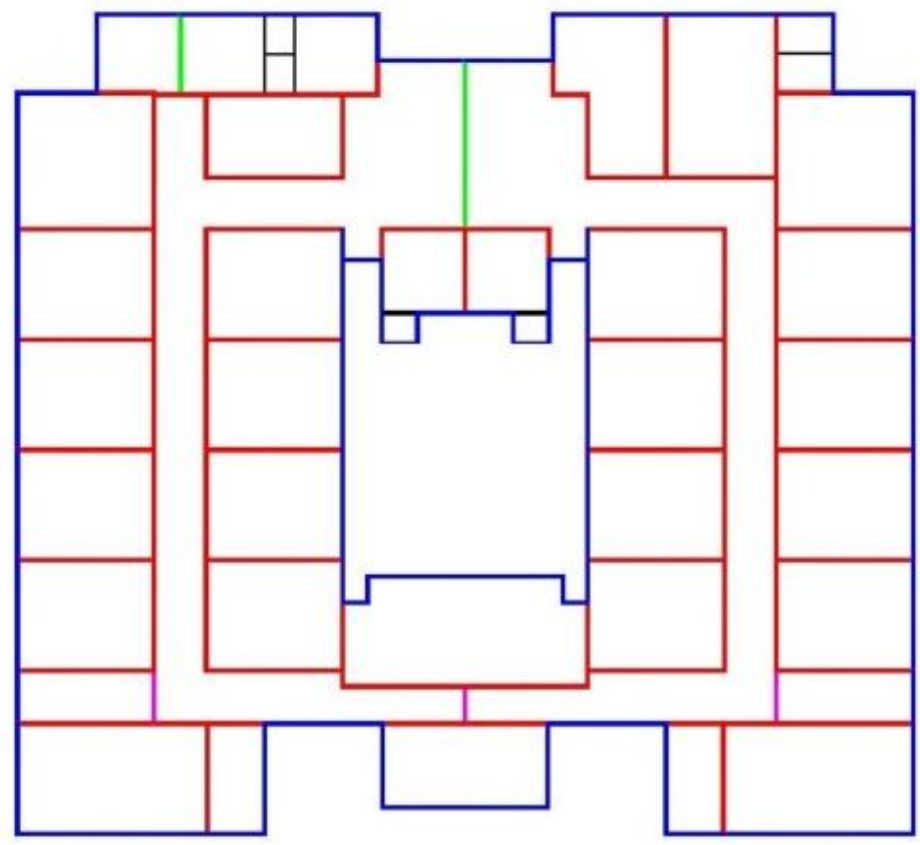

Figure 3. 2D Architectural plan for manual cost estimation 
For manual cost estimation Table 3 to 7 have been prepared. Table 3 presents the quantities calculation of brickwork and of reinforced concrete slab. Table 3 has ten columns altogether, in description column name of item to be calculated is presented, in the column of No, the number of items of this description from the floor plan is presented, then under the measurements, the length, breadth, and the height of a particular item is presented, deduction are made for an item which is within another item, for e.g. quantities of windows are deducted from the wall sections as they lie within the wall section. Quantities are calculated by multiplying the measurements of length, breadth, and height. Then to get the total quantities the deduction are subtracted from the quantities. Net calculated quantities of brick work and reinforced concrete slab are 19475 and $10947 \mathrm{cft}$ shown in Table 3.

Table 3. Calculation of brick work and RCC slab

\begin{tabular}{|c|c|c|c|c|c|c|c|c|c|}
\hline \multirow{2}{*}{$\begin{array}{l}\text { Sr. } \\
\text { No }\end{array}$} & \multirow{2}{*}{ Description } & \multirow{2}{*}{ No } & \multicolumn{3}{|c|}{ Measurement } & \multirow{2}{*}{ Deduction } & \multirow{2}{*}{ Quantity } & \multirow{2}{*}{ Unit } & \multirow{2}{*}{ Total } \\
\hline & & & $\mathbf{L}$ & B & $\mathbf{H}$ & & & & \\
\hline \multirow[t]{28}{*}{1} & BW in super structure & & & & & & & & \\
\hline & Red wall Section & 1 & 1381.5 & 0.75 & 12 & & 12433.5 & $\mathrm{cft}$ & \\
\hline & Windows & 35 & 5 & 0.75 & 5 & 656.25 & & $\mathrm{cft}$ & \\
\hline & Windows & 6 & 8 & 0.75 & 5 & 180 & & $\mathrm{cft}$ & \\
\hline & Windows & 2 & 5 & 0.75 & 3 & 22.5 & & $\mathrm{cft}$ & \\
\hline & Windows & 4 & 6 & 0.75 & 5 & 90 & & $\mathrm{cft}$ & \\
\hline & Windows & 2 & 5 & 0.75 & 7.5 & 56.25 & & $\mathrm{cft}$ & \\
\hline & Windows & 3 & 3 & 0.75 & 3 & 20.25 & & $\mathrm{cft}$ & \\
\hline & Windows & 6 & 9 & 0.75 & 9 & 364.5 & & $\mathrm{cft}$ & \\
\hline & Windows & 4 & 6 & 0.375 & 2 & 18 & & $\mathrm{cft}$ & \\
\hline & Windows & 4 & 2 & 0.75 & 2 & 12 & & $\mathrm{cft}$ & \\
\hline & Windows & 2 & 15.75 & 0.75 & 12 & 283.5 & & $\mathrm{cft}$ & \\
\hline & Windows & 2 & 10 & 0.75 & 5 & 75 & & $\mathrm{cft}$ & \\
\hline & Windows & 2 & 12.5 & 0.75 & 5 & 93.75 & & $\mathrm{cft}$ & \\
\hline & Door & 2 & 5 & 0.75 & 8 & 60 & & $\mathrm{cft}$ & \\
\hline & Door & 2 & 3.5 & 0.75 & 5 & 26.25 & & $\mathrm{cft}$ & \\
\hline & Blue wall Section & 1 & 1009.33 & 0.75 & 12 & & 9083.97 & $\mathrm{cft}$ & \\
\hline & Door & 25 & 5 & 0.75 & 8 & 750 & & $\mathrm{cft}$ & \\
\hline & Door & 8 & 3.5 & 0.75 & 8 & 168 & & $\mathrm{cft}$ & \\
\hline & Door & 2 & 2.5 & 0.75 & 8 & 30 & & $\mathrm{cft}$ & \\
\hline & Magenta wall Section & 1 & 20 & 0.75 & 12 & & 180 & $\mathrm{cft}$ & \\
\hline & Door & 2 & 3.5 & 0.75 & 8 & 42 & & $\mathrm{cft}$ & \\
\hline & Green wall Section & 1 & 62.18 & 0.75 & 12 & & 559.57 & $\mathrm{cft}$ & \\
\hline & Door & 1 & 5 & 0.75 & 8 & 30 & & $\mathrm{cft}$ & \\
\hline & Black wall Section & 1 & 47 & 0.375 & 12 & & 211.50 & $\mathrm{cft}$ & \\
\hline & Door & 2 & 2.5 & 0.375 & 8 & 15 & & $\mathrm{cft}$ & \\
\hline & Net & & & & & 2993.25 & 22468.55 & & 19475.30 \\
\hline & Total brickwork & & & & & & & $\mathrm{cft}$ & 19475.30 \\
\hline \multirow[t]{2}{*}{2} & Reinforced Concrete Slab & 1 & \multicolumn{2}{|c|}{21895} & 0.5 & & 10947.5 & $\mathrm{cft}$ & \\
\hline & & & & & & & Total & $\mathrm{cft}$ & 10947.5 \\
\hline
\end{tabular}

Similarly, Table 4 presents the quantities calculation of plaster work and paint work. Table 4 has ten columns altogether, in description column, name of item to be calculated is presented in this case windows, doors, plaster work, and paint work. In the column of No, the number of items of this description from the floor plan is presented, then under the measurements, the length, breadth, and the height of a particular item is presented, deduction are made for an item which is within another item, for e.g. quantities of windows are deducted from the plaster and paint work on the wall sections as they lie within the wall section. Quantities of plaster and paint work has been made twice because the plaster and paint are applied on both sides of the wall sections. Similarly, quantities are calculated by multiplying the measurements of length, breadth, and height. Then to get the total quantities the deduction is subtracted from the quantities. Net calculated quantities of Plaster and white wash is 52702 sft shown in Table 4. 
Table 4 Calculation of Plaster work and Paint work

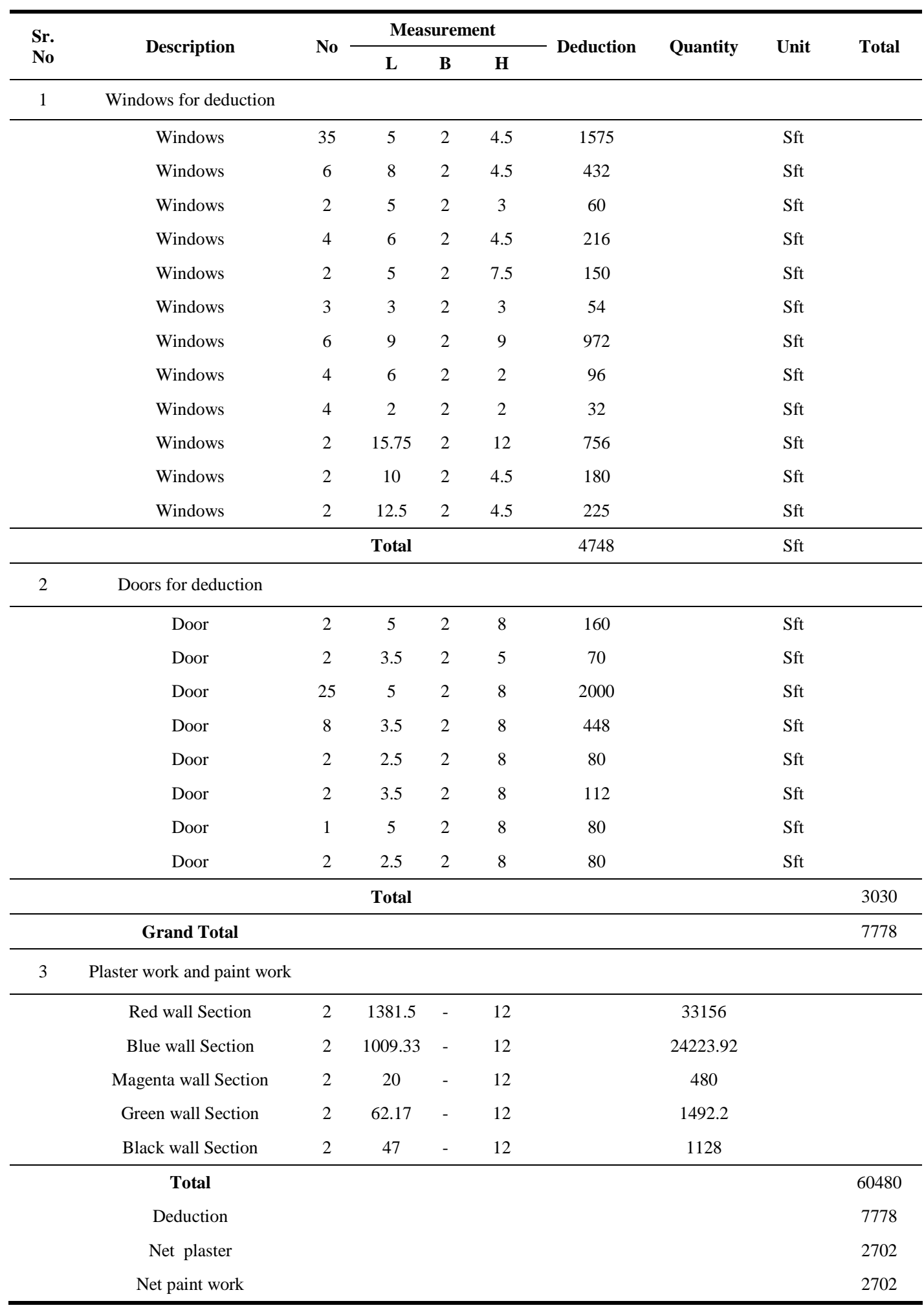

On similar grounds Table 5 has been prepared. In this table calculations for Plain Cement Concrete (PCC) for flooring, floor tile work, and false ceiling are presented. Wall sections have been deducted to get the total net area of the room to calculate the net required quantities of PCC flooring, tile work, and false ceiling. Net calculated quantities for PCC Flooring, Floor Tile Work and False Ceiling is 5001, 20005, and 20005 sft as shown in Table 5. 
Table 5. Calculation of PCC for Flooring, Floor Tile Work and False Ceiling

\begin{tabular}{|c|c|c|c|c|c|c|c|c|c|}
\hline \multirow{2}{*}{$\begin{array}{l}\text { Sr. } \\
\text { No }\end{array}$} & \multirow{2}{*}{ Description } & \multirow{2}{*}{ No } & \multicolumn{3}{|c|}{ Measurement } & \multirow{2}{*}{ Deduction } & \multirow{2}{*}{ Quantity } & \multirow{2}{*}{ Unit } & \multirow{2}{*}{ Total } \\
\hline & & & $\mathbf{L}$ & B & $\mathbf{H}$ & & & & \\
\hline \multirow[t]{8}{*}{1} & Walls for deduction & & & & & & & & \\
\hline & Blue wall Section & 1 & 1009.33 & 0.75 & - & & 757 & $\mathrm{Sft}$ & \\
\hline & Magenta wall Section & 1 & 20 & 0.75 & - & & 15 & $\mathrm{Sft}$ & \\
\hline & Green wall Section & 1 & 62.175 & 0.75 & - & & 46.63 & $\mathrm{Sft}$ & \\
\hline & Black wall Section & 1 & 47 & 0.75 & - & & 35.25 & $\mathrm{Sft}$ & \\
\hline & Total & & & & & & 853.88 & $\mathrm{Sft}$ & \\
\hline & Total building area & & & & & & 20859 & Sft & \\
\hline & Net area of rooms & & & & & 853.88 & 20859 & Sft & 20005 \\
\hline 2 & PCC for Flooring & & $20859 \mathrm{Sft}$ & 0.25 & & & & $\mathrm{cft}$ & 5001 \\
\hline 3 & Floor Tile Work & & & & & & 20005 & $\mathrm{Sft}$ & \\
\hline 4 & False Ceiling & & & & & & 20005 & Sft & \\
\hline
\end{tabular}

Calculation of windows and doors are presented in Table 6. In this table quantities of windows and doors have been calculated by multiplying their length, breadth, and height. No deduction is made in these quantities. Net calculated quantities of windows and doors $2374 \mathrm{sft}$ and $1515 \mathrm{sft}$ as shown in Table 6.

Table 6. Calculation of windows and doors

\begin{tabular}{|c|c|c|c|c|c|c|c|c|c|}
\hline \multirow{2}{*}{$\begin{array}{l}\text { Sr. } \\
\text { No }\end{array}$} & \multirow{2}{*}{ Description } & \multirow{2}{*}{ No } & \multicolumn{3}{|c|}{ Measurement } & \multirow{2}{*}{ Deduction } & \multirow{2}{*}{ Quantity } & \multirow{2}{*}{ Unit } & \multirow{2}{*}{ Total } \\
\hline & & & $\mathbf{L}$ & B & $\mathbf{H}$ & & & & \\
\hline \multirow[t]{14}{*}{1} & Window Calculations & & & & & & & & \\
\hline & Windows & 35 & 5 & 0.75 & 4.5 & & 787.5 & $\mathrm{Sft}$ & \\
\hline & Windows & 6 & 8 & 0.75 & 4.5 & & 216 & $\mathrm{Sft}$ & \\
\hline & Windows & 2 & 5 & 0.75 & 3 & & 30 & $\mathrm{Sft}$ & \\
\hline & Windows & 4 & 6 & 0.75 & 4.5 & & 108 & $\mathrm{Sft}$ & \\
\hline & Windows & 2 & 5 & 0.75 & 7.5 & & 75 & $\mathrm{Sft}$ & \\
\hline & Windows & 3 & 3 & 0.75 & 3 & & 27 & $\mathrm{Sft}$ & \\
\hline & Windows & 6 & 9 & 0.75 & 9 & & 486 & $\mathrm{Sft}$ & \\
\hline & Windows & 4 & 6 & 0.375 & 2 & & 48 & $\mathrm{Sft}$ & \\
\hline & Windows & 4 & 2 & 0.75 & 2 & & 16 & $\mathrm{Sft}$ & \\
\hline & Windows & 2 & 15.75 & 0.75 & 12 & & 378 & $\mathrm{Sft}$ & \\
\hline & Windows & 2 & 10 & 0.75 & 4.5 & & 90 & $\mathrm{Sft}$ & \\
\hline & Windows & 2 & 12.5 & 0.75 & 4.5 & & 112.5 & $\mathrm{Sft}$ & \\
\hline & & & & & & & Total & Sft & 2374 \\
\hline \multirow[t]{10}{*}{2} & Doors Calculation & & & & & & & & \\
\hline & Door & 2 & 5 & 0.75 & 8 & & 80 & $\mathrm{Sft}$ & \\
\hline & Door & 2 & 3.5 & 0.75 & 5 & & 35 & $\mathrm{Sft}$ & \\
\hline & Door & 25 & 5 & 0.75 & 8 & & 1000 & $\mathrm{Sft}$ & \\
\hline & Door & 8 & 3.5 & 0.75 & 8 & & 224 & $\mathrm{Sft}$ & \\
\hline & Door & 2 & 2.5 & 0.75 & 8 & & 40 & $\mathrm{Sft}$ & \\
\hline & Door & 2 & 3.5 & 0.75 & 8 & & 56 & $\mathrm{Sft}$ & \\
\hline & Door & 1 & 5 & 0.75 & 8 & & 40 & $\mathrm{Sft}$ & \\
\hline & Door & 2 & 2.5 & 0.375 & 8 & & 40 & $\mathrm{Sft}$ & \\
\hline & & & & & & & Total & Sft & 1515.000 \\
\hline
\end{tabular}

Calculation of skirting is presented in Table 7. In this table quantities of wall sections have been taken in Rft on both sides of the wall skirting would be provided that is why lengths of wall sections have been taken twice. Lengths of doors have to be deducted from the skirting as skirting is not provided on doors. Net calculation of skirting is $3838 \mathrm{Rft}$ as shown in Table 7. 
Table 7. Calculation of Skirting

\begin{tabular}{|c|c|c|c|c|c|c|c|c|}
\hline \multirow{2}{*}{$\begin{array}{l}\text { Sr. } \\
\text { No }\end{array}$} & \multirow{2}{*}{ Description } & \multirow{2}{*}{ No } & \multicolumn{3}{|c|}{ Measurement } & \multirow{2}{*}{ Deduction } & \multirow{2}{*}{ Quantity } & \multirow{2}{*}{ Unit } \\
\hline & & & $\mathbf{L}$ & B & $\mathbf{H}$ & & & \\
\hline \multirow[t]{10}{*}{1} & Doors for deduction & & & & & & & \\
\hline & Door & 2 & 5 & & - & 10 & & $\mathrm{Rft}$ \\
\hline & Door & 2 & 3.5 & & - & 7 & & Rft \\
\hline & Door & 25 & 5 & & - & 125 & & Rft \\
\hline & Door & 8 & 3.5 & & - & 28 & & Rft \\
\hline & Door & 2 & 2.5 & & - & 5 & & Rft \\
\hline & Door & 2 & 3.5 & & - & 7 & & Rft \\
\hline & Door & 1 & 5 & & - & 5 & & Rft \\
\hline & Door & 2 & 2.5 & & - & 5 & & $\mathrm{Rft}$ \\
\hline & & & & & Total & 192 & & Rft \\
\hline \multirow[t]{9}{*}{2} & Total walls length & & & & & & & \\
\hline & Red wall Section & 2 & 1381.5 & - & - & - & 2763 & Rft \\
\hline & Blue wall Section & 1 & 1009.33 & - & - & - & 1009.33 & Rft \\
\hline & Magenta wall Section & 2 & 20 & - & - & - & 40 & $\mathrm{Rft}$ \\
\hline & Green wall Section & 2 & 62.175 & - & - & - & 124.35 & Rft \\
\hline & Black wall Section & 2 & 47 & - & - & - & 94 & Rft \\
\hline & Total & & & & & & 4030.68 & $\mathrm{Rft}$ \\
\hline & & & & & & Deduction & 192 & $\mathrm{Rft}$ \\
\hline & Total skirting & & & & & & 3838.68 & $\mathrm{Rft}$ \\
\hline
\end{tabular}

\subsubsection{Bill of Quantities for Manual Cost Estimation}

BOQ sheet is prepared during the step of calculation of material and it shows the quantities of items, unit cost of items, and total cost of project by manual cost estimation. Total estimated cost of the project is Rs 30967389 by manual cost estimation $(1000$ Rs (Pakistani Rupee $)=6.42 \$(U S$ Dollar $))$. This BOQ sheet includes the total quantities and cost of materials to be used in the construction of project. The BOQ sheet is shown in Table 8.

Table 8. BOQ for manual cost estimation results

\begin{tabular}{cccccc}
\hline Sr.no & Item Description & Unit & Quantity & Unit Cost & Total Cost \\
\hline 1 & Brick Work in Super Structure & Cft & 19475 & 222 & 4323450 \\
2 & RCC Slab & Cft & 10947 & 360 & 3940920 \\
3 & Plaster Work & Sft & 52702 & 180 & 9486360 \\
4 & PCC for Flooring & Cft & 5001.25 & 135 & 675168.75 \\
5 & Floor Tile Work & Sft & 20005 & 300 & 6001500 \\
6 & Skirting & Rft & 3838 & 100 & 383800 \\
7 & Paint Work & Sft & 52447 & 45 & 2360115 \\
8 & False Ceiling & Sft & 20005 & 65 & 1300325 \\
9 & Doors & Sft & 2375 & 700 & 1662500 \\
10 & Aluminium Work & Sft & 1515 & 550 & 833250 \\
\hline \multicolumn{5}{r}{} & Total
\end{tabular}

\subsection{Revit Software/ BIM based Estimation Process:}

Cost estimation by using Revit software is carried out by the following steps:

1. 2D drawing/plan of the structure is drawn as shown in Figure 4.

2. After this from the view tab in software, 3D model was generated without roof as shown in Figure 5(a) and with roof as shown in Figure 5(b) [21]. Cross sections and elevations are shown in Figure 6(a), (b), and (c).

3. To estimate the cost of structure elements, sheets of quantities is generated in the schedule option of the view tab of Revit software as shown in Figure 7(a) and Table 9(a) for room areas, Figure 7(b) and Table 9 (b) for quantities of brickwork material. 


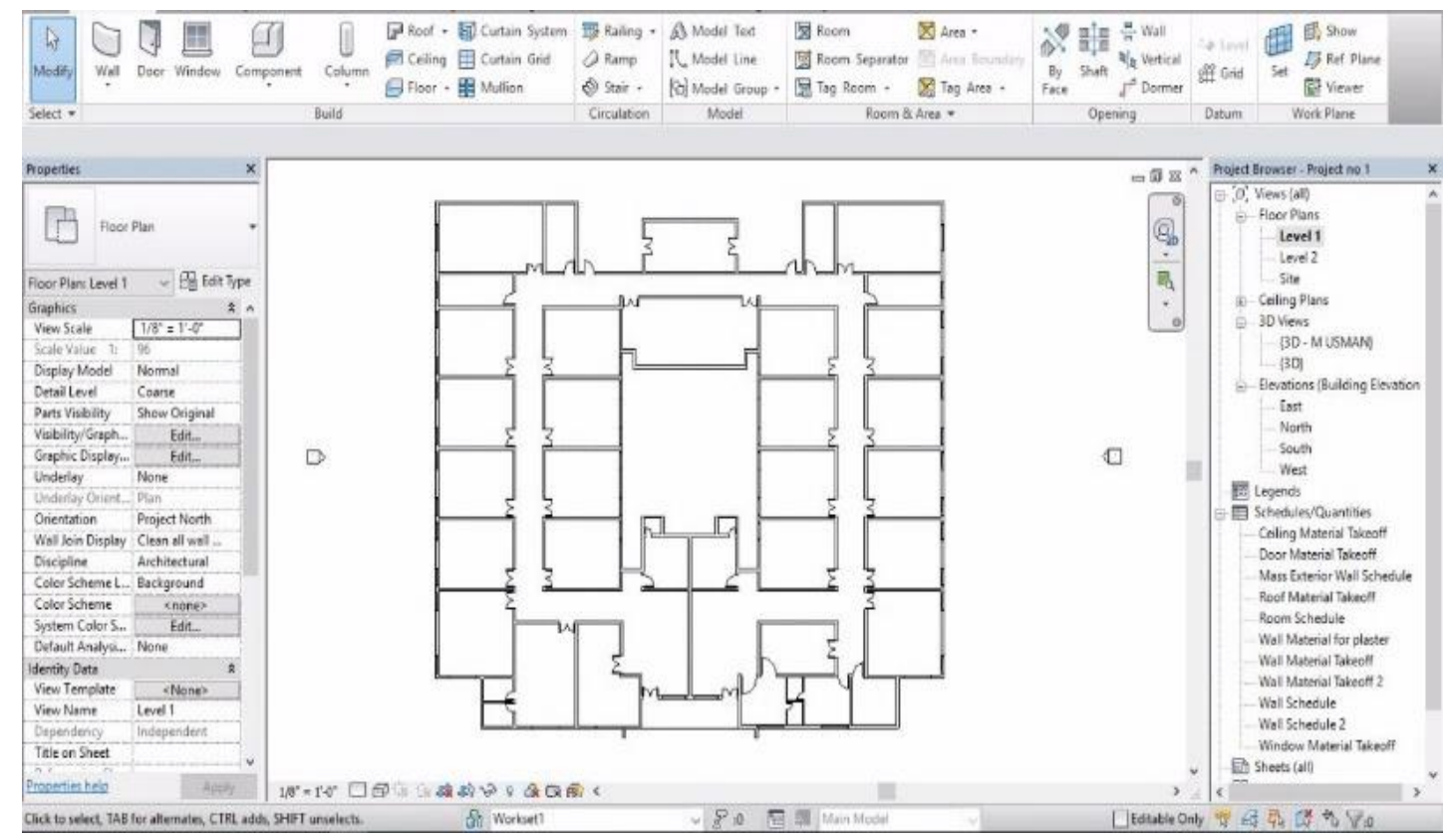

Figure 4. 2D Drawing for cost estimation in Revit software
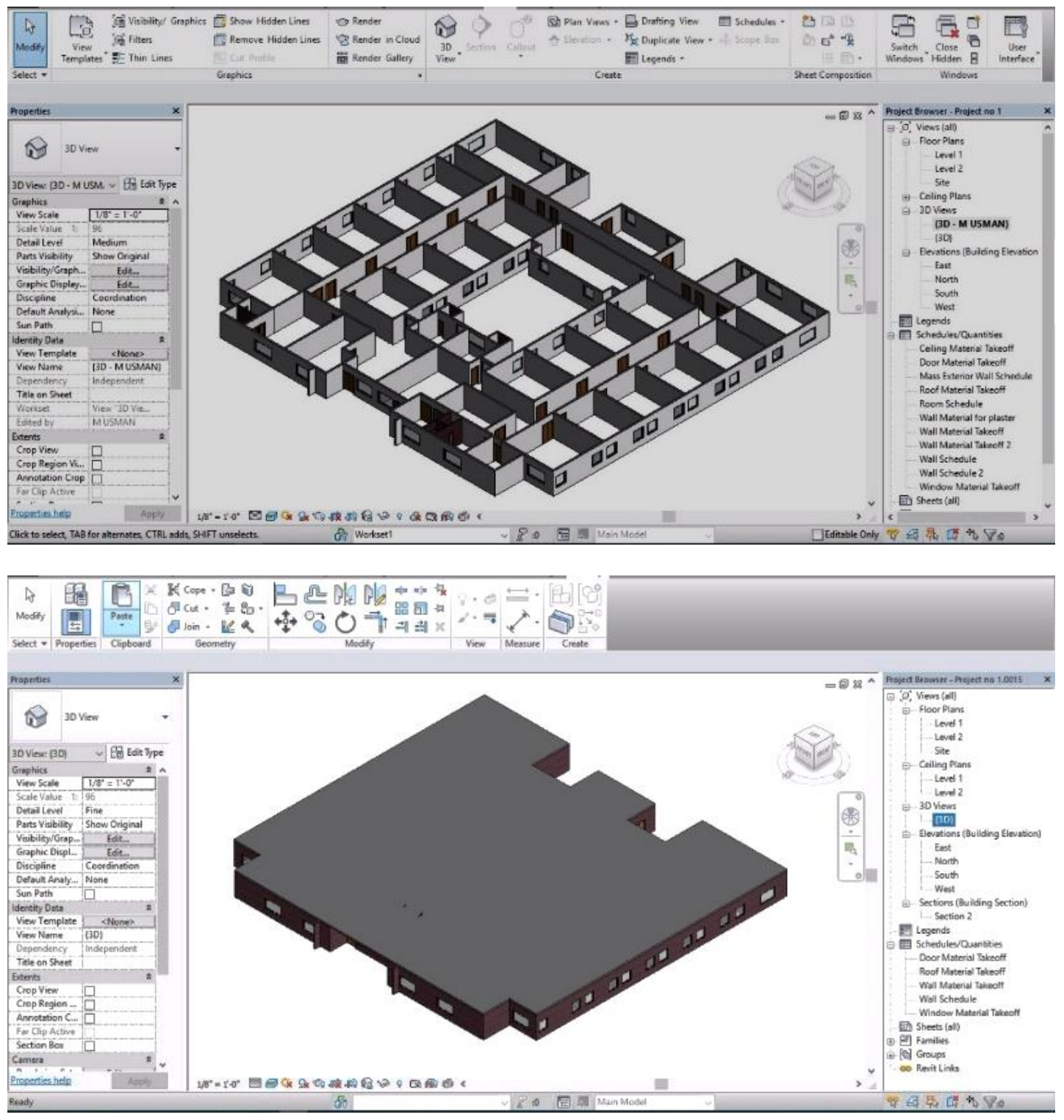

Figure 5. 3D Drawing for cost estimation in Revit software: without roof (a), with roof $(b)$ 


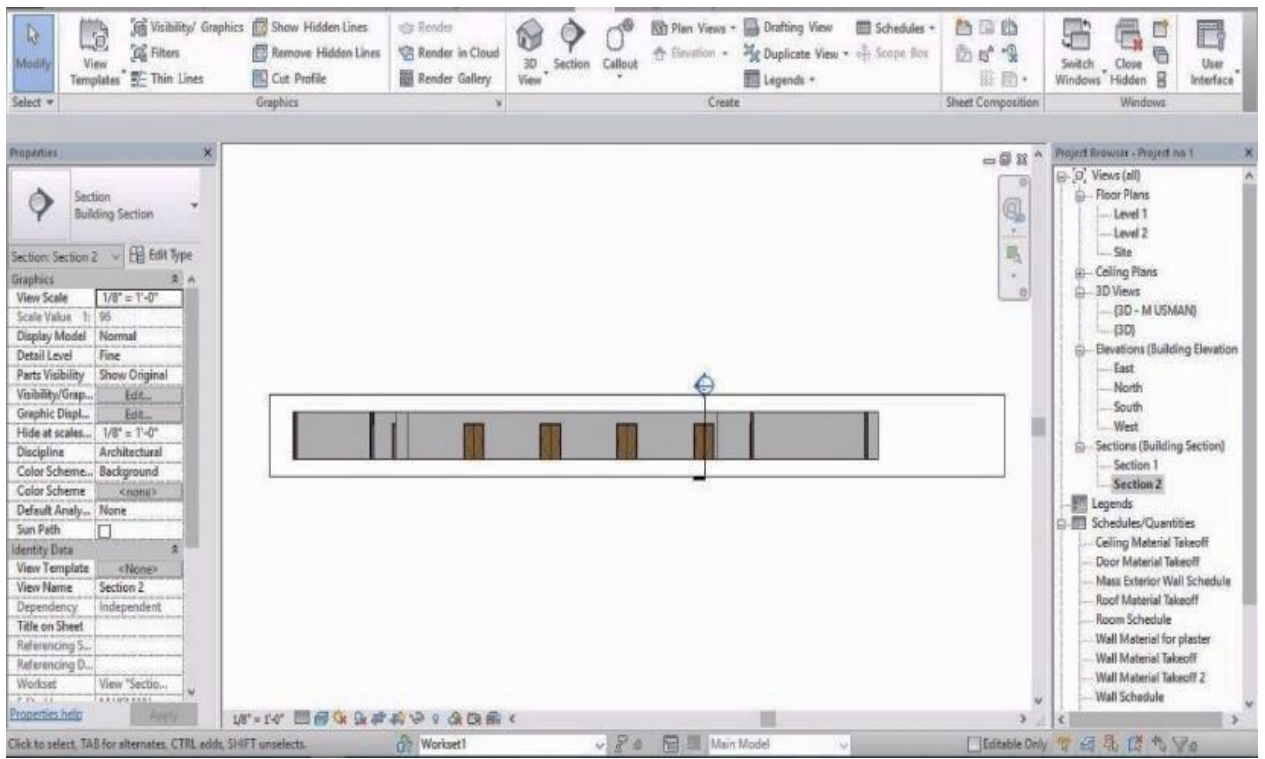

(a)

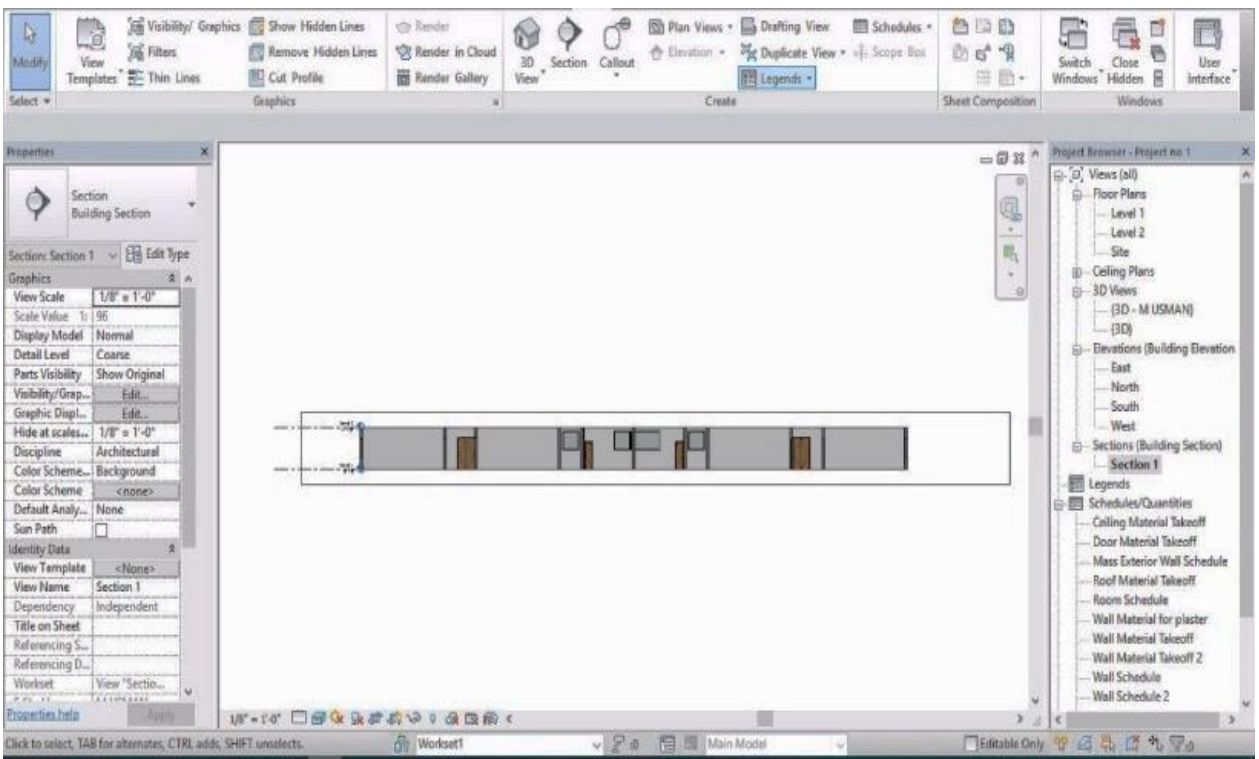

(b)

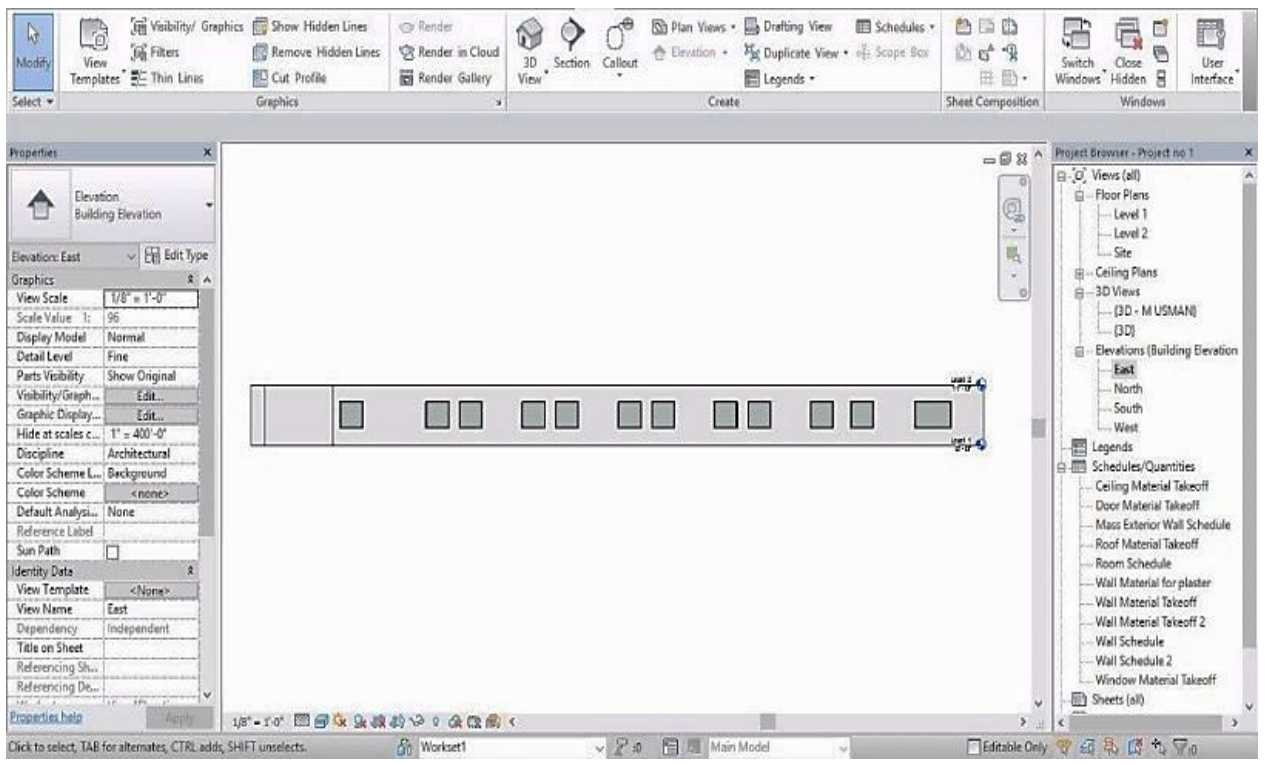

(c)

Figure 6. (a) Cross section 1-1, (b) Cross section 2-2, (c) East side elevation 


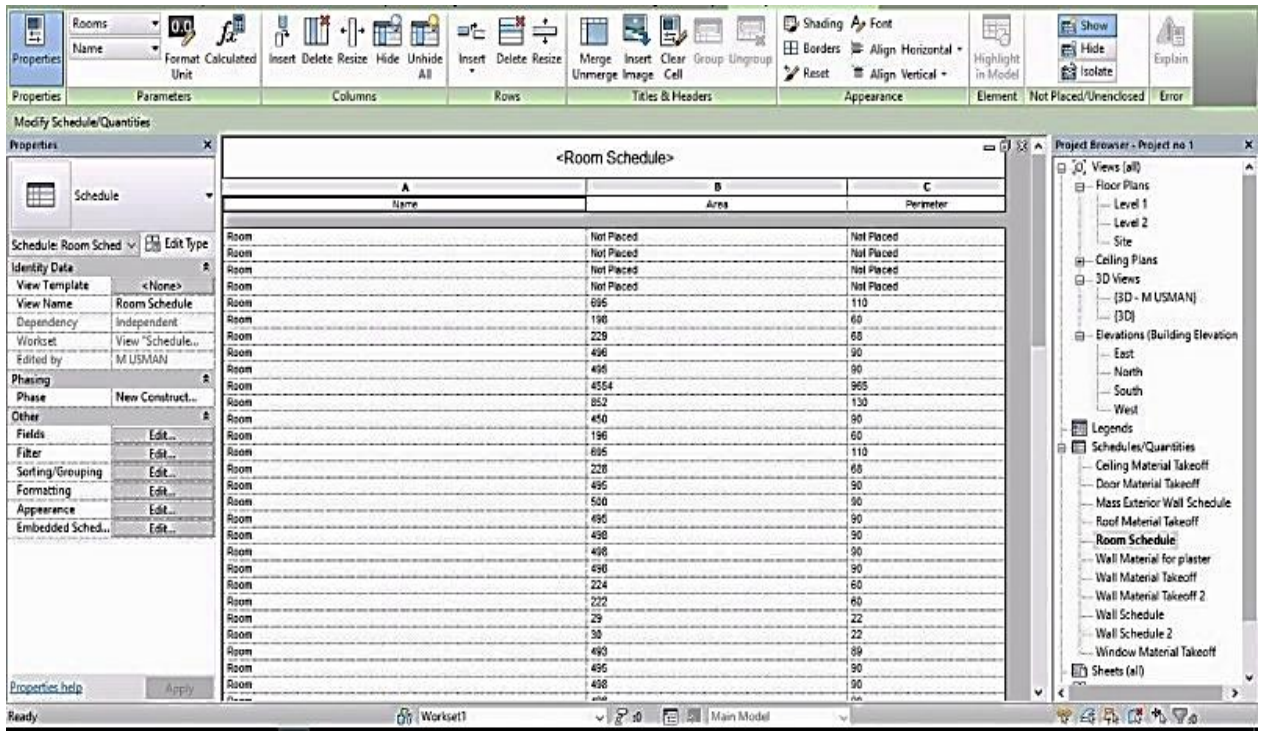

(a)

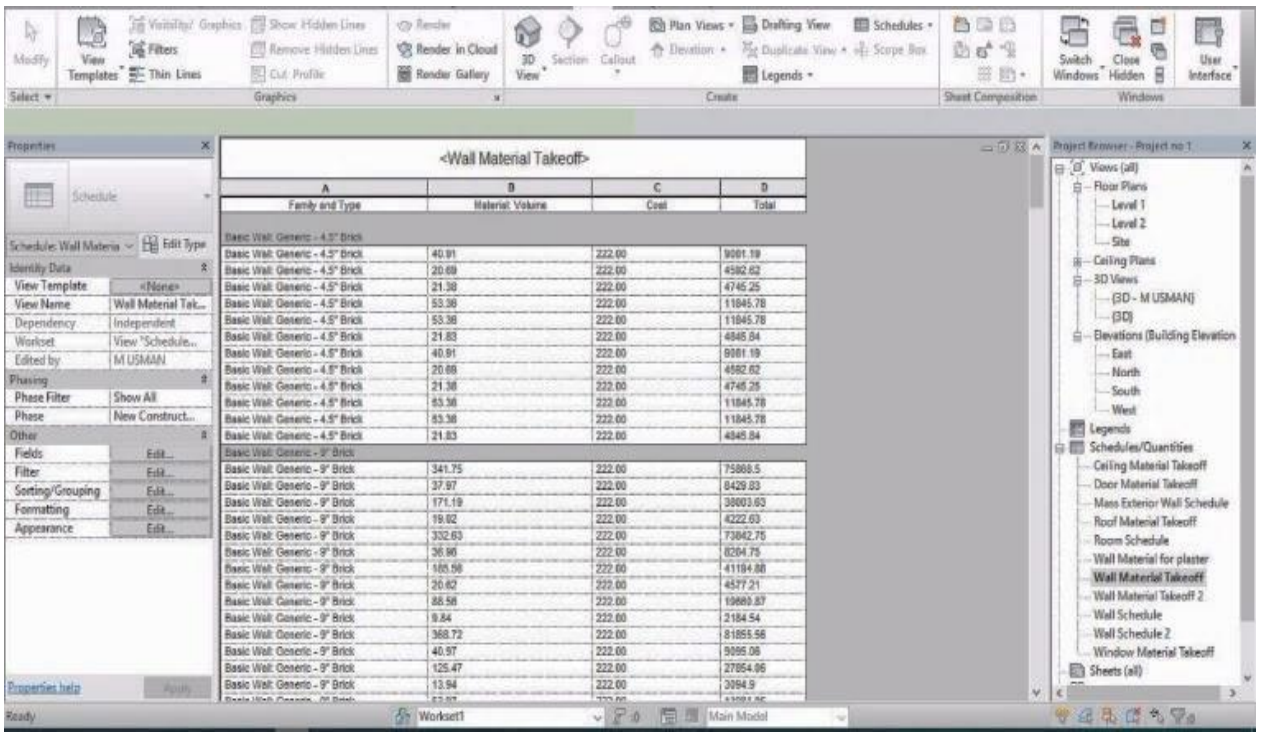

(b)

Figure 7. (a) Room Schedule, (b) Wall Material / brickwork

Table 9. (a) Room Schedule

\begin{tabular}{|c|c|c|c|c|c|c|c|c|}
\hline Name & Area & Perimeter & Name & Area & Perimeter & Name & Area & Perimeter \\
\hline Room & Not Placed & Not Placed & Room & 500 & $90^{\prime}-0^{\prime \prime}$ & Room & 66 & $33^{\prime}-2^{\prime \prime}$ \\
\hline Room & Not Placed & Not Placed & Room & 495 & $89^{\prime}-6^{\prime \prime}$ & Room & 68 & $33^{\prime}-7^{\prime \prime}$ \\
\hline Room & Not Placed & Not Placed & Room & 498 & $89^{\prime}-10^{\prime \prime}$ & Room & 367 & $79^{\prime}-3^{\prime \prime}$ \\
\hline Room & Not Placed & Not Placed & Room & 498 & $89^{\prime}-10^{\prime \prime}$ & Room & 212 & $58^{\prime}-3^{\prime \prime}$ \\
\hline Room & 695 & $109^{\prime}-8^{\prime \prime}$ & Room & 498 & $89^{\prime}-10^{\prime \prime}$ & Room & 37 & $24^{\prime}-5^{\prime \prime}$ \\
\hline Room & 198 & $59^{\prime}-8^{\prime \prime}$ & Room & 224 & $59^{\prime}-10^{\prime \prime}$ & Room & 37 & $24^{\prime}-5^{\prime \prime}$ \\
\hline Room & 229 & $68^{\prime}-4^{\prime \prime}$ & Room & 222 & $59^{\prime}-7^{\prime \prime}$ & Room & 215 & $58^{\prime}-9^{\prime \prime}$ \\
\hline Room & 496 & $89^{\prime}-8^{\prime \prime}$ & Room & 29 & $21^{\prime}-8^{\prime \prime}$ & Room & 209 & $57^{\prime}-6^{\prime \prime}$ \\
\hline Room & 495 & $89^{\prime}-6^{\prime \prime}$ & Room & 30 & $22^{\prime}-0^{\prime \prime}$ & Room & 617 & $99^{\prime}-4^{\prime \prime}$ \\
\hline Room & 4554 & $965^{\prime}-1^{\prime \prime}$ & Room & 493 & $89^{\prime}-4^{\prime \prime}$ & Room & 495 & $89^{\prime}-6^{\prime \prime}$ \\
\hline Room & 852 & $130^{\prime}-1^{\prime \prime}$ & Room & 495 & $89^{\prime}-6^{\prime \prime}$ & Room & 495 & $89^{\prime}-6^{\prime \prime}$ \\
\hline Room & 450 & $90^{\prime}-2^{\prime \prime}$ & Room & 498 & $89^{\prime}-10^{\prime \prime}$ & Room & 500 & $90^{\prime}-0^{\prime \prime}$ \\
\hline Room & 196 & $59^{\prime}-6^{\prime \prime}$ & Room & 498 & $89^{\prime}-10^{\prime \prime}$ & Room & 495 & $89^{\prime}-6^{\prime \prime}$ \\
\hline Room & 695 & $109^{\prime}-8^{\prime \prime}$ & Room & 623 & $99^{\prime}-10^{\prime \prime}$ & Room & 279 & $81^{\prime}-8^{\prime \prime}$ \\
\hline Room & 228 & $68^{\prime}-0^{\prime \prime}$ & Room & 596 & $99^{\prime}-9^{\prime \prime}$ & \multirow{2}{*}{\multicolumn{3}{|c|}{20386}} \\
\hline Room & 495 & $89^{\prime}-6^{\prime \prime}$ & Room & 514 & $101^{\prime}-1 "$ & & & \\
\hline
\end{tabular}


Table 9. (b) Wall Material / Brickwork

\begin{tabular}{|c|c|c|c|c|c|}
\hline Family and Type & $\begin{array}{c}\text { Material: } \\
\text { Volume }\end{array}$ & Family and Type & $\begin{array}{c}\text { Material: } \\
\text { Volume }\end{array}$ & Family and Type & $\begin{array}{c}\text { Material: } \\
\text { Volume }\end{array}$ \\
\hline Basic Wall: Generic - 9" Brick & 341.06 & Basic Wall: Generic - 9" Brick & 101.55 & Basic Wall: Generic - 9" Brick & 206.25 \\
\hline Basic Wall: Generic - 9" Brick & 37.9 & Basic Wall: Generic - 9" Brick & 178 & Basic Wall: Generic - 9" Brick & 22.92 \\
\hline Basic Wall: Generic - 9" Brick & 170.5 & Basic Wall: Generic - 9" Brick & 19.78 & Basic Wall: Generic - 9" Brick & 206.25 \\
\hline Basic Wall: Generic - 9" Brick & 18.94 & Basic Wall: Generic - 9" Brick & 801.12 & Basic Wall: Generic - 9" Brick & 22.92 \\
\hline Basic Wall: Generic - 9" Brick & 331.94 & Basic Wall: Generic - 9" Brick & 89.01 & Basic Wall: Generic - 9" Brick & 204.88 \\
\hline Basic Wall: Generic - 9" Brick & 36.88 & Basic Wall: Generic - 9" Brick & 219.31 & Basic Wall: Generic - 9" Brick & 22.76 \\
\hline Basic Wall: Generic - 9" Brick & 185.56 & Basic Wall: Generic - 9" Brick & 24.37 & Basic Wall: Generic - 9" Brick & 206.25 \\
\hline Basic Wall: Generic - 9" Brick & 20.62 & Basic Wall: Generic - 9" Brick & 24.75 & Basic Wall: Generic - 9" Brick & 22.92 \\
\hline Basic Wall: Generic - 9" Brick & 88.56 & Basic Wall: Generic - 9" Brick & 2.75 & Basic Wall: Generic - 9" Brick & 247.5 \\
\hline Basic Wall: Generic - 9" Brick & 9.84 & Basic Wall: Generic - 9" Brick & 319.5 & Basic Wall: Generic - 9" Brick & 27.5 \\
\hline Basic Wall: Generic - 9" Brick & 368.72 & Basic Wall: Generic - 9" Brick & 35.5 & Basic Wall: Generic - 9" Brick & 204.88 \\
\hline Basic Wall: Generic - 9" Brick & 40.97 & Basic Wall: Generic - 9" Brick & 597 & Basic Wall: Generic - 9" Brick & 22.76 \\
\hline Basic Wall: Generic - 9" Brick & 125.47 & Basic Wall: Generic - 9" Brick & 66.33 & Basic Wall: Generic - 9" Brick & 204.88 \\
\hline Basic Wall: Generic - 9" Brick & 13.94 & Basic Wall: Generic - 9" Brick & 213.13 & Basic Wall: Generic - 9" Brick & 22.76 \\
\hline Basic Wall: Generic - 9" Brick & 53.97 & Basic Wall: Generic - 9" Brick & 23.68 & Basic Wall: Generic - 9" Brick & 163.63 \\
\hline Basic Wall: Generic - 9" Brick & 6 & Basic Wall: Generic - 9" Brick & 558.56 & Basic Wall: Generic - 9" Brick & 18.18 \\
\hline Basic Wall: Generic - 9" Brick & 98.91 & Basic Wall: Generic - 9" Brick & 62.06 & Basic Wall: Generic - 9" Brick & 38.16 \\
\hline Basic Wall: Generic - 9" Brick & 10.99 & Basic Wall: Generic - 9" Brick & 213.13 & Basic Wall: Generic - 9" Brick & 4.24 \\
\hline Basic Wall: Generic - 9" Brick & 262.88 & Basic Wall: Generic - 9" Brick & 23.68 & Basic Wall: Generic - 9" Brick & 40.56 \\
\hline Basic Wall: Generic - 9" Brick & 29.21 & Basic Wall: Generic - 9" Brick & 206.25 & Basic Wall: Generic - 9" Brick & 4.51 \\
\hline Basic Wall: Generic - 9" Brick & 669.81 & Basic Wall: Generic - 9" Brick & 22.92 & Basic Wall: Generic - 9" Brick & 267.06 \\
\hline Basic Wall: Generic - 9" Brick & 74.42 & Basic Wall: Generic - 9" Brick & 206.25 & Basic Wall: Generic - 9" Brick & 29.67 \\
\hline Basic Wall: Generic - 9" Brick & 213.13 & Basic Wall: Generic - 9" Brick & 22.92 & Basic Wall: Generic - 9" Brick & 37.47 \\
\hline Basic Wall: Generic - 9" Brick & 23.68 & Basic Wall: Generic - 9" Brick & 206.25 & Basic Wall: Generic - 9" Brick & 4.16 \\
\hline Basic Wall: Generic - 9" Brick & 133.63 & Basic Wall: Generic - 9" Brick & 22.92 & Basic Wall: Generic - 9" Brick & 33.69 \\
\hline Basic Wall: Generic - 9" Brick & 14.85 & Basic Wall: Generic - 9" Brick & 204.88 & Basic Wall: Generic - 9" Brick & 3.74 \\
\hline Basic Wall: Generic - 9" Brick & 114.94 & Basic Wall: Generic - 9" Brick & 22.76 & Basic Wall: Generic - 9" Brick & 42.09 \\
\hline Basic Wall: Generic - 9" Brick & 12.77 & Basic Wall: Generic - 9" Brick & 204.88 & Basic Wall: Generic - 9" Brick & 4.68 \\
\hline Basic Wall: Generic - 9" Brick & 125.81 & Basic Wall: Generic - 9" Brick & 22.76 & Basic Wall: Generic - 9" Brick & 126.84 \\
\hline Basic Wall: Generic - 9" Brick & 13.98 & Basic Wall: Generic - 9" Brick & 204.88 & Basic Wall: Generic - 9" Brick & 14.09 \\
\hline Basic Wall: Generic - 9" Brick & 907.31 & Basic Wall: Generic - 9" Brick & 22.76 & Basic Wall: Generic - 9" Brick & 26.44 \\
\hline Basic Wall: Generic - 9" Brick & 100.81 & Basic Wall: Generic - 9" Brick & 204.88 & Basic Wall: Generic - 9" Brick & 2.94 \\
\hline Basic Wall: Generic - 9" Brick & 99.94 & Basic Wall: Generic - 9" Brick & 22.76 & Basic Wall: Generic - 9" Brick & 260.56 \\
\hline Basic Wall: Generic - 9" Brick & 11.1 & Basic Wall: Generic - 9" Brick & 164.31 & Basic Wall: Generic - 9" Brick & 28.95 \\
\hline Basic Wall: Generic - 9" Brick & 218.25 & Basic Wall: Generic - 9" Brick & 18.26 & Basic Wall: Generic - 9" Brick & 153.28 \\
\hline Basic Wall: Generic - 9" Brick & 24.25 & Basic Wall: Generic - 9" Brick & 571.56 & Basic Wall: Generic - 9" Brick & 17.03 \\
\hline Basic Wall: Generic - 9" Brick & 93.06 & Basic Wall: Generic - 9" Brick & 63.51 & Basic Wall: Generic - 9" Brick & 179.5 \\
\hline Basic Wall: Generic - 9" Brick & 10.34 & Basic Wall: Generic - 9" Brick & 211.75 & Basic Wall: Generic - 9" Brick & 19.94 \\
\hline Basic Wall: Generic - 9" Brick & 171.19 & Basic Wall: Generic - 9" Brick & 23.53 & Basic Wall: Generic - 9" Brick & 378.12 \\
\hline Basic Wall: Generic - 9" Brick & 19.02 & Basic Wall: Generic - 9" Brick & 557.19 & Basic Wall: Generic - 9" Brick & 42.01 \\
\hline Basic Wall: Generic - 9" Brick & 304.19 & Basic Wall: Generic - 9" Brick & 61.91 & Basic Wall: Generic - 9" Brick & 44.34 \\
\hline Basic Wall: Generic - 9" Brick & 33.8 & Basic Wall: Generic - 9" Brick & 206.25 & Basic Wall: Generic - 9" Brick & 4.93 \\
\hline Basic Wall: Generic - 9" Brick & 913.94 & Basic Wall: Generic - 9" Brick & 22.92 & Basic Wall: Generic - 9" Brick & 44.34 \\
\hline Basic Wall: Generic - 9" Brick & 4.93 & Basic Wall: Generic - 9" Brick & 145.38 & Basic Wall: Generic - 9" Brick & 57.56 \\
\hline Basic Wall: Generic - 9" Brick & 121.69 & Basic Wall: Generic - 9" Brick & 117.22 & Basic Wall: Generic - 9" Brick & 6.4 \\
\hline Basic Wall: Generic - 9" Brick & 13.52 & Basic Wall: Generic - 9" Brick & 13.02 & Basic Wall: Generic - 4.5" Brick & 20.69 \\
\hline Basic Wall: Generic - 9" Brick & 367.34 & Basic Wall: Generic - 9" Brick & 218.63 & Basic Wall: Generic - 4.5" Brick & 21.38 \\
\hline
\end{tabular}




\begin{tabular}{|c|c|c|c|c|c|}
\hline Basic Wall: Generic - 9" Brick & 40.82 & Basic Wall: Generic - 9" Brick & 24.29 & Basic Wall: Generic - 4.5" Brick & 53.36 \\
\hline Basic Wall: Generic - 9" Brick & 124.09 & Basic Wall: Generic - 9" Brick & 122.03 & Basic Wall: Generic - 4.5" Brick & 53.36 \\
\hline Basic Wall: Generic - 9" Brick & 13.79 & Basic Wall: Generic - 9" Brick & 13.56 & Basic Wall: Generic - 9" Brick & 24.75 \\
\hline Basic Wall: Generic - 9" Brick & 237.63 & Basic Wall: Generic - 9" Brick & 92.03 & Basic Wall: Generic - 9" Brick & 2.75 \\
\hline Basic Wall: Generic - 9" Brick & 26.4 & Basic Wall: Generic - 9" Brick & 10.23 & Basic Wall: Generic - 9" Brick & 24.06 \\
\hline Basic Wall: Generic - 9" Brick & 22.76 & Basic Wall: Generic - 9" Brick & 204.88 & Basic Wall: Generic - 9" Brick & 2.67 \\
\hline Basic Wall: Generic - 9" Brick & 33.84 & Basic Wall: Generic - 9" Brick & 16.15 & Basic Wall: Generic - 4.5" Brick & 21.83 \\
\hline Basic Wall: Generic - 9" Brick & 3.76 & Basic Wall: Generic - 9" Brick & 702.81 & & Total: \\
\hline Basic Wall: Generic-4.5" Brick & 40.91 & Basic Wall: Generic - 9" Brick & 78.09 & & 20408.74 \\
\hline
\end{tabular}

\subsubsection{Bill of Quantities for BIM / Revit Software Based Cost Estimation}

BOQ sheet is prepared like Manual BOQ sheet but the difference here is that the quantities of the items are calculated by BIM / Revit Software. Quantities calculated by BIM / Revit Software [22] are more accurate than manual estimation. Total estimated cost of the project is Rs 32453745 by BIM / Revit Software cost estimation. The BOQ sheet is shown in Table 10.

Table 10 BIM / Revit Software Cost Estimation Results

\begin{tabular}{clcccc}
\hline Sr.no & Item Description & Unit & Quantity & UNIT COST & Total Cost \\
\hline 1 & Brick Work in Super Structure & $\mathrm{Cft}$ & 20408 & 222 & 4530576 \\
2 & RCC Slab & $\mathrm{Cft}$ & 11240 & 360 & 4046400 \\
3 & Plaster Work & $\mathrm{Sft}$ & 57025 & 180 & 10264500 \\
4 & PCC for Flooring & $\mathrm{Cft}$ & 5170 & 135 & 698004 \\
5 & Floor Tile Work & $\mathrm{Sft}$ & 20386 & 300 & 6115800 \\
6 & Skirting & $\mathrm{Rft}$ & 4115 & 100 & 411500 \\
7 & Paint Work & $\mathrm{Sft}$ & 57025 & 45 & 2566125 \\
8 & False Ceiling & $\mathrm{Sft}$ & 20386 & 65 & 1325090 \\
9 & Doors & $\mathrm{Sft}$ & 2375 & 700 & 1662500 \\
10 & Aluminum Work & $\mathrm{Sft}$ & 1515 & 550 & 833250 \\
\hline & & & & Total & RS-32453745 \\
\hline
\end{tabular}

\subsubsection{Levels of design based on CAD and BIM}

As per the literature there are four Levels of design based on CAD and BIM which can be distinguished from each other as shown in Table 11[23]. The present research as per the literature falls in Level 1 and 2.

Table 11. Levels of BIM

\begin{tabular}{cl}
\hline Level & \multicolumn{1}{c}{ Description } \\
\hline 0 & Contains any kind of paper documentation, created by hand or with the aid of CAD programs. \\
1 & Concerns documentation 2D and 3D in the form of digital files without use of a detailed database \\
2 & Starting level of building information modelling \\
3 & Intelligent BIM (iBIM), which makes construction management possible throughout life cycle of the design. \\
\hline
\end{tabular}

\subsection{Cost Comparison between Revit and Manual Methods}

The main purpose of the cost estimation is to find the accurate value of the project before construction. Quantities calculated by BIM / Revit Software are more accurate than manual [24]. Total estimated cost of the project by manual cost estimation is Rs 30967389 and Rs 32453745 by BIM / Revit Software as shown in Table 10. The comparison of quantities of items is shown in Figure 8. The difference of the Project cost comes out to be 4.8\%. It has been found that the quantities estimated by BIM / Revit Software are more accurate due to the accuracy of the BIM / Revit software estimation [25]. The Percentage difference between Manual and BIM / Revit Software estimation in brick work, RCC Slab, Plaster Work, PCC for Flooring, Floor Tile Work, Skirting, Paint Work, False Ceiling, Doors and Aluminium Work is $4.57 \%, 2.61 \%, 7.58 \%, 3.27 \%, 1.87 \%, 6.73 \%, 8.03 \%, 1.87 \%, 0.00 \%$ and $0.00 \%$ as shown in Figure 9. The study conducted by shen and Issa (2010) [26] also showed that the BIM-assisted estimate had better performance over traditional/manual estimating methods. Both the visualization and aggregation functions of the BIM-Assisted Detailed Estimating (BADE) tool had significant impact on the performance of the detailed estimate. Study by shen and Issa 
(2010) [26] further found that the more complex the estimating tasks, the clearer the advantages were of using BADE tools instead of traditional/manual estimating methods.

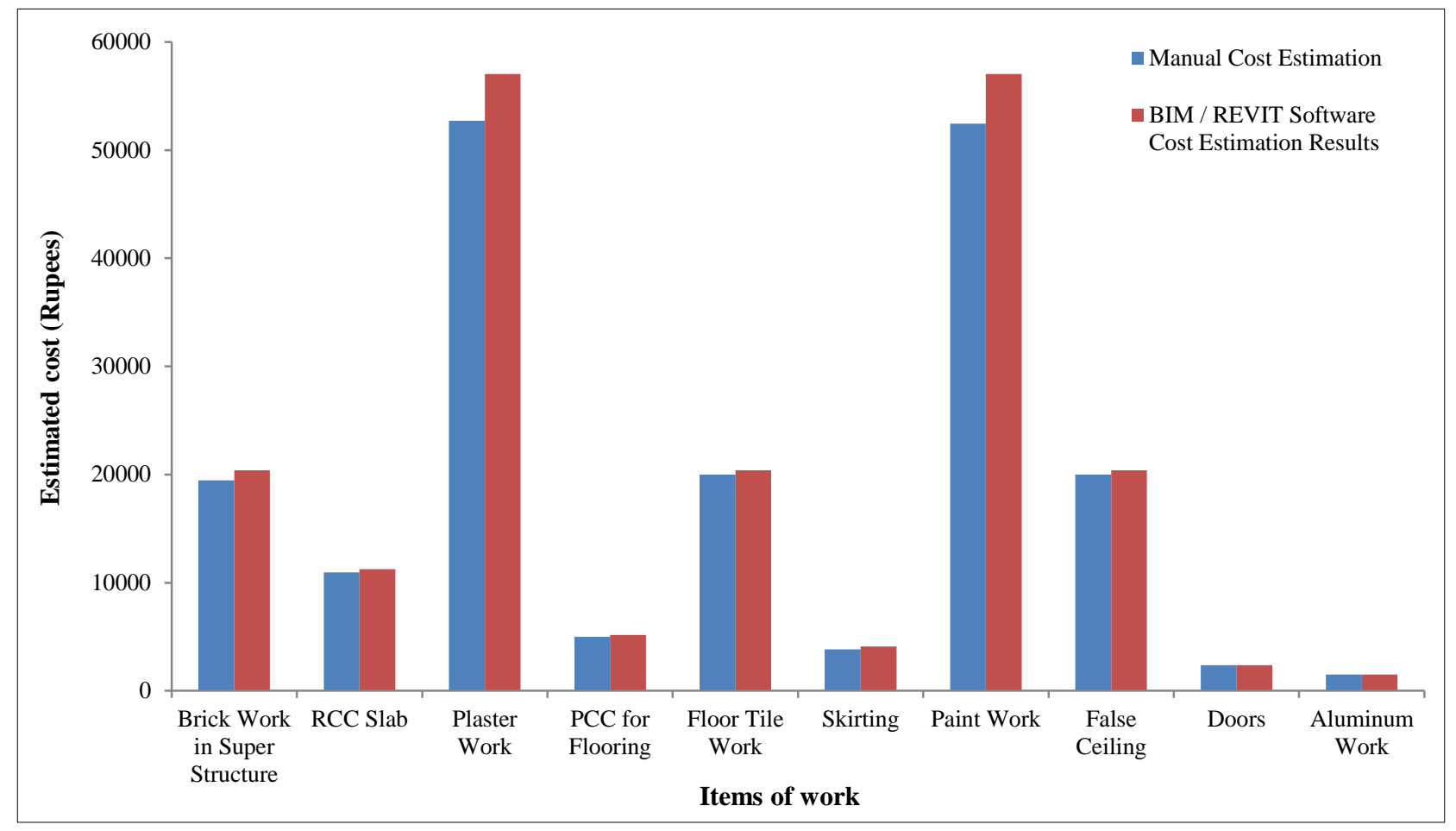

Figure 8. Comparison of cost by Manual and BIM software for each item

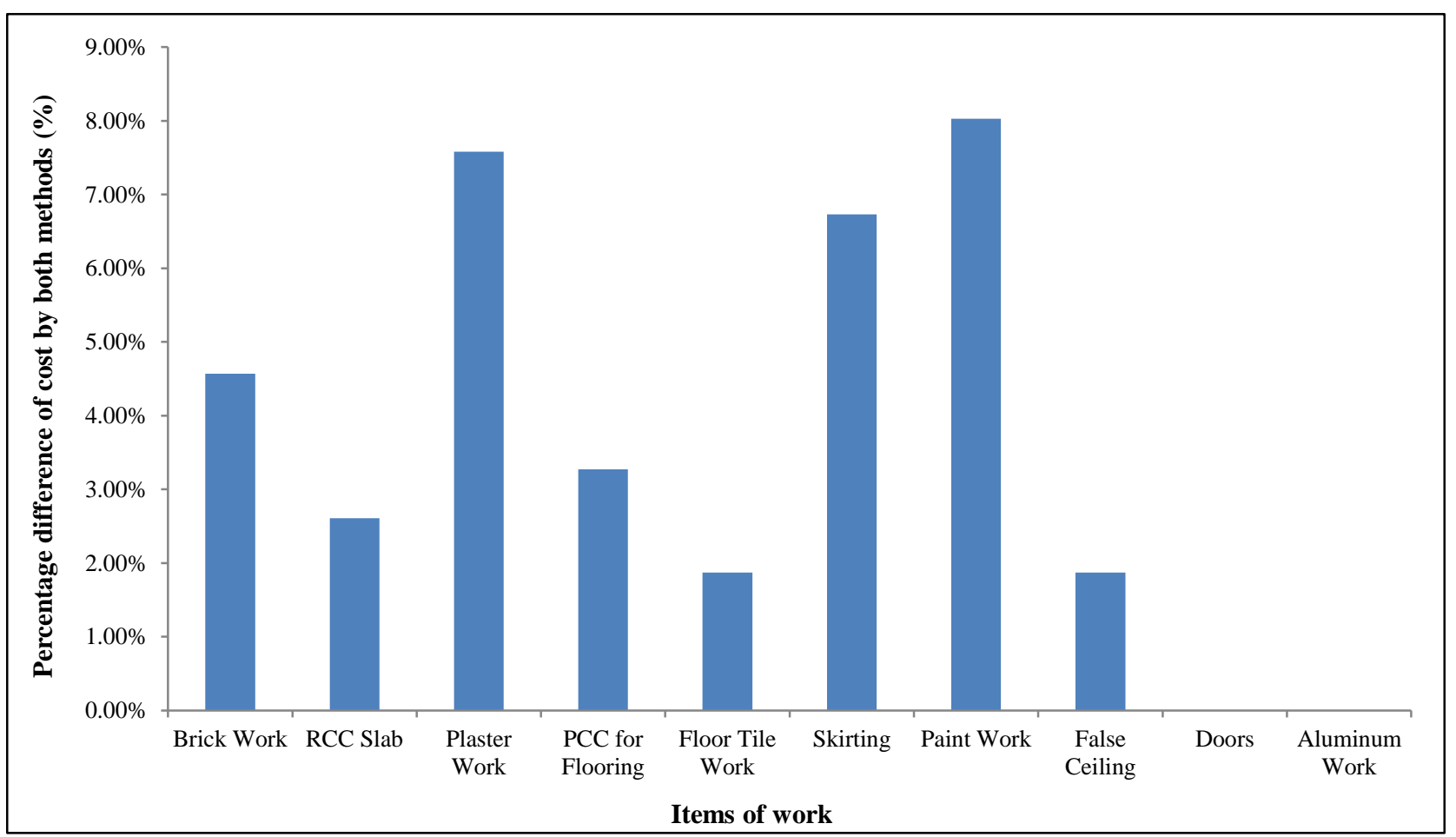

Figure 9. Percentage difference of cost by both methods (\%)

\section{Conclusions}

The following points are concluded from this research:

- Manual work is hectic, time taking and there are much chances of error, whereas estimation on Revit Software is fast, easy, efficient, automatic, and have less chances of error. 
- The manual work includes manual calculation work and there are chances of error because some formulas are long and complex, while in Revit Software there is no need to calculate manually, just model can be drawn and measurements can be inserted to get material quantities.

- In manual work each task has to be considered e.g. quantities calculation, material calculation, abstract of cost etc. while in Revit software it is be automatic.

- It is difficult to rectify errors or to make changes in manual, while in Revit Software it is very easy.

- The usual practice in the field for doing manual cost estimation is that full room sizes are considered, whereas, for the BIM software cost estimation due to subtracting wall plasters, the room sizes are reduced. This causes the difference of cost for BIM based cost estimation approach.

- The other reasons for different costs of project calculated by BIM software based approach compared with manual is that finishing items such as plastering, flooring and skirting consist of quantities which are not considered in the manual cost estimate.

\section{Conflicts of Interest}

The authors declare no conflict of interest.

\section{References}

[1] Yu, Wen-der, Chien-chung Lai, and Wan-li Lee. "A WICE Approach to Real-Time Construction Cost Estimation." Automation in Construction 15, no. 1 (January 2006): 12-19. doi:10.1016/j.autcon.2005.01.005.

[2] Gurcanli, G. Emre, Senem Bilir, and Merve Sevim. "Activity Based Risk Assessment and Safety Cost Estimation for Residential Building Construction Projects.” Safety Science 80 (December 2015): 1-12. doi:10.1016/j.ssci.2015.07.002.

[3] Engineeringfeed, how to Calculate Rough Cost Estimate for Building, Available online: Engineeringfeed.com/calculate-roughcost-estimate-building (accessed on 1 May 2019).

[4] Emeraldgroup-learning, Detailed Cost Estimating, Available online: https://emeraldgroup-learning.ca/detailed-cost-estimating/ (accessed on 1 May 2019).

[5] Abanda, F.H., B. Kamsu-Foguem, and J.H.M. Tah. "BIM - New Rules of Measurement Ontology for Construction Cost Estimation." Engineering Science and Technology, an International Journal 20, no. 2 (April 2017): $443-459$. doi:10.1016/j.jestch.2017.01.007.

[6] Gharpedia.com, Sthapati Designers \& Consultants Pvt. Ltd, Available online: https://gharpedia.com/center-line-method-ofestimation/ (accessed on 12 May 2019).

[7] Finance Department, Government of Punjab, Market rates system Bi-Annual period 2019, Available online: https://finance.punjab.gop.pk/mrs (accessed on 18 April 2019).

[8] Rezaian, Amin. "Time-cost-quality-risk of construction and development projects or investment." Middle-East Journal of Scientific Research 10, no. 2 (2011): 218-223.

[9] Lee, Seul-Ki, Ka-Ram Kim, and Jung-Ho Yu. "BIM and Ontology-Based Approach for Building Cost Estimation.” Automation in Construction 41 (May 2014): 96-105. doi:10.1016/j.autcon.2013.10.020.

[10] Alfredo Serpell, José Manuel Rueda, Estimating the Cost of New Construction Projects Using an Integrated, Computer-Based Approach, Creative Construction Conference 2013, July 6 - 9, 2013, Budapest, Hungary.

[11] Guo, Hongling, Run Yu, and Yihai Fang. "Analysis of negative impacts of BIM-enabled information transparency on contractors' interests." Automation in Construction 103 (2019): 67-79. doi: 10.1016/j.autcon.2019.03.007.

[12] Fountain, James, and Sandeep Langar. "Building Information Modeling (BIM) Outsourcing among General Contractors." Automation in Construction 95 (November 2018): 107-117. doi:10.1016/j.autcon.2018.06.009.

[13] Heaton, James, Ajith Kumar Parlikad, and Jennifer Schooling. "Design and Development of BIM Models to Support Operations and Maintenance.” Computers in Industry 111 (October 2019): 172-186. doi:10.1016/j.compind.2019.08.001.

[14] Hasan, Ahmed M.M., Ahmed A. Torky, and Youssef F. Rashed. "Geometrically Accurate Structural Analysis Models in BIMCentered Software.” Automation in Construction 104 (August 2019): 299-321. doi:10.1016/j.autcon.2019.04.022.

[15] Khosakitchalert, Chavanont, Nobuyoshi Yabuki, and Tomohiro Fukuda. "Improving the Accuracy of BIM-Based Quantity Takeoff for Compound Elements.” Automation in Construction 106 (October 2019): 102891. doi:10.1016/j.autcon.2019.102891.

[16] Baldwin, Andrew N., and Anthony Thorpe. "Information Technology for Construction Cost Estimating." Habitat International 14, no. 2-3 (January 1990): 157-163. doi:10.1016/0197-3975(90)90045-3. 
[17] Liu, Zhe, and Zhiliang Ma. "Establishing Formalized Representation of Standards for Construction Cost Estimation by Using Ontology Learning.” Procedia Engineering 123 (2015): 291-299. doi:10.1016/j.proeng.2015.10.093.

[18] Cheng, Min-Yuan, Hsing-Chih Tsai, and Erick Sudjono. "Conceptual Cost Estimates Using Evolutionary Fuzzy Hybrid Neural Network for Projects in Construction Industry.” Expert Systems with Applications 37, no. 6 (June 2010): 4224-4231. doi:10.1016/j.eswa.2009.11.080.

[19] Feng, Guang Li, and Li Li. “Application of Genetic Algorithm and Neural Network in Construction Cost Estimate.” Advanced Materials Research 756-759 (September 2013): 3194-3198. doi:10.4028/www.scientific.net/amr.756-759.3194.

[20] Autodesk, BIM and Cost Estimating, Available online: http://www.autodesk.com/revit (accessed on 1 May 2019).

[21] Zhiliang, Ma, and Wei Zhenhua. "Framework for automatic construction cost estimation based on BIM and ontology technology." In Proceedings of the CIB W78 2012: 29th International Conference. 2012.

[22] Kim, Gwang-Hee, Sung-Hoon An, and Kyung-In Kang. "Comparison of Construction Cost Estimating Models Based on Regression Analysis, Neural Networks, and Case-Based Reasoning.” Building and Environment 39, no. 10 (October 2004): 1235-1242. doi:10.1016/j.buildenv.2004.02.013.

[23] Czmoch, Ireneusz, and Adam Pękala. “Traditional Design versus BIM Based Design.” Procedia Engineering 91 (2014): $210-$ 215. doi:10.1016/j.proeng.2014.12.048.

[24] Juszczyk, Michał. "The Challenges of Nonparametric Cost Estimation of Construction Works with the Use of Artificial Intelligence Tools.” Procedia Engineering 196 (2017): 415-422. doi:10.1016/j.proeng.2017.07.218.

[25] Plebankiewicz, Edyta, Krzysztof Zima, and Mirosław Skibniewski. "Analysis of the First Polish BIM-Based Cost Estimation Application.” Procedia Engineering 123 (2015): 405-414. doi:10.1016/j.proeng.2015.10.064.

[26] Shen, Zhigang, and Raja RA Issa. "Quantitative evaluation of the BIM-assisted construction detailed cost estimates." (2010). 